\title{
Penatalayanan Musik Gereja Di Masa Pandemi Covid-19
}

\author{
Agus Budi Handoko \\ Institut Agama Kristen Negeri Palangka Raya \\ handokoagusbudi@gmail.com
}

\begin{abstract}
The problem of the Covid-19 outbreak has an impact on worship activities in churches which have changed the model to the use of online worship. Church music as part of worship is certainly prepared in online worship so it needs stewardship so that it can take place well. The purpose of this study is to explain the impact of the Covid-19 pandemic on the stewardship of church music in worship. The research method uses a qualitative approach and the type is descriptive narrative. The research location is at the Kalawa Congregation GKE, Kasongan Regency, Central Kalimantan. The results of the study found that the Covid-19 pandemic had an impact or influence on church life, whether it was a negative impact that became an obstacle or a positive impact that became a strength.
\end{abstract}

Keywords: stewardship; church music; covid-19 pandemic

\begin{abstract}
Abstrak
Permasalahan wabah Covid-19 berdampak dalam kegiatan ibadah di gereja yang berubah model ke penggunaan ibadah online. Musik Gereja sebagai bagian dari ibadah tentu dipersiapkan dalam ibadah online sehingga perlu penatalayanan agar bisa berlangsung dengan baik. Tujuan penelitian ini adalah menjelaskan dampak pandemi Covid-19 penatalayanan musik gereja dalam ibadah. Metode penelitian menggunakan pendekatan kualitatif dan jenisnya adalah deskriptif naratif. Lokasi tempat penelitian adalah di GKE Jemaat Kalawa, Kabupaten Kasongan, Kalimantan Tengah. Hasil penelitian dijumpai bahwa pandemi Covid-19 membawa dampak atau pengaruh dalam kehidupan bergereja, baik itu dampak negatif yang menjadi hambatan ataupun juga dampak positif yang menjadi kekuatan.
\end{abstract}

Kata Kunci: penatalayanan; musik gereja; pandemi covid-19

\section{Pendahuluan}

Dalam perkembangan upaya penanganan Covid-19 di Indonesia, Kementerian Agama Dirjen Bimas Kristen pada tanggal 20 Maret 2020 mengeluarkan surat edaran yang isinya menghimbau kepada gereja-gereja untuk menggunakan alternatif persekutuan dan ibadah dengan memanfaatkan media sosial dan teknologi digital yaitu dengan mengganti sementara model kebaktian Minggu dengan ibadah online agar proses ibadah bisa tetap berlangsung tanpa adanya aktivitas kontak langsung sesama warga jemaat. Gereja dapat membantu membatasi bahkan menghentikan penyebaran Covid-19 dengan berusaha menghindari kumpulan orang banyak, menunda sementara kegiatankegiatan rutin gerejawi, menyelenggarakan kebaktian pemakaman dengan sangat bijaksana yang mempertimbangkan protokol kesehatan dan jika dimungkinkan menunda kebaktian pernikahan, yang diiringi dengan kepedulian yang kuat bukan hanya pada diri sendiri tetapi juga pada orang lain. Semenjak itu hingga sekarang (penelitian ini dibuat), 
pelaksanaan ibadah yang dilakukan di gereja-gereja yang ada diarahkan untuk menggunakan ibadah secara daring atau online, yaitu ibadah dengan menggunakan media internet karena untuk menghindari pertemuan kontak erat langsung atau kontak fisik di antara sesama jemaat di gedung gereja.

Ibadah online dilakukan jemaat tanpa harus datang langsung dalam ibadah di gedung gereja, tetapi bisa dilakukan secara mandiri dari rumah masing-masing sehingga sering juga disebut sebagai ibadah rumah. Ibadah di rumah masing-masing cukup dilaksanakan dengan mengakses internet lewat aplikasi media online dari manapun dan kapanpun diperlukan atau sesuai jadwal ibadah yang sudah ditentukan. Media online yang digunakan biasanya menggunakan media aplikasi online (youtube, instagram, facebook, dll), kemudian pelaksanaan penyiarannya bisa dilakukan dengan cara penyiaran langsung (live streaming) ataupun rekaman video yang sudah diunggah ke media online.

Ibadah online bukanlah model ibadah yang biasa dilakukan oleh gereja sehingga dibutuhkan persiapan-persiapan khusus dan bahkan baru apabila dibanding dengan pelaksanaan ibadah konvensional seperti biasanya. Ibadah online dalam pelaksanaannya dibutuhkan penyesuai dalam pengeloannya, bahkan juga karena melakukan sesutu yang baru yang biasanya juga akan muncul permasalah atau kendala yang akan dihadapi. Pengelolaan atau penatayalanan ibadah online menjadi hal yang sangat penting untuk diteliti, secara khusus juga melingkupi pelayanan bidang musik gereja. Musik gereja tetap diperlukan keberadaannya untuk menunjang agar ibadah online dapat berlangsung dengan baik. Keberadaan musik gereja perlu dikelola atau ditata dengan baik untuk menunjang keberhasilan ibadah online seperti juga penatalayanan yang sudah biasa dilakukan dalam ibadah konvensional.

GKE Jemaat Kalawa di Kabupaten Kasongan Kalimantan Tengah merupakan salah satu dari gereja-gereja di Indonesia yang terdampak virus Covid-19 yang juga menerapkan bentuk ibadah online sebagai bentuk pelayanan penyediaan sarana ibadah bagi anggota jemaat yang ada. Sebagai gereja yang berada di ruang lingkup kabupaten yang tidak terlalu besar, sumber daya dan sarana terbatas tentunya mengalami permasalahan atau kendala dalam melaksanakan ibadah online, begitu juga termasuk dengan penalayanan musik gereja di dalamnya.

GKE Jemat Kalawa dijadikan sebagai tempat penelitian karena kondisi gerejanya diperkirakan berada di tengah, di antara gereja besar dan gereja kecil, kemudian tempatnya juga berada kota kabupaten, bukan di kota besar dan juga di desa yang kecil, sehingga diharapkan GKE Kalawa, baik secara status maupun keberadaan dapat mewakili semua gereja yang terdampak pandemi Covid-19 dan yang menggunakan bentuk ibadah online.

\section{Metode}

Pendekatan dalam penelitian ini menggunakan pendekatan kualitatif dan jenisnya adalah deskriptif naratif yaitu penelitian yang bersifat penjelasan analisis data. Hal yang ditekankan dalam penelitian ini ialah gambaran mengenai fenomena yang terjadi pada 
subyek penelitian sesuai dengan data yang terkumpul. Teknik pengumpulan data menggunakan tahapan observasi lapangan, wawancara, dan kemudian diolah dan dianalisis.

\section{Hasil dan Pembahasan}

\section{Dampak Masa Pandemi Covid-19 Terhadap Pelayanan Musik Gereja}

Ibadah online adalah sebagai bentuk atau model ibadah yang dilaksanakan sebagai dampak dari masa pandemi Covid-19. Ibadah online berbeda dengan ibadah konvensional yang normal seperti biasanya, ibadah online adalah ibadah yang dilaksanakan atau diakses dengan menggunakan media online atau lewat internet, atau ibadah yang didistribusikan melalui internet. Ibadah online hanya dihadiri secara langsung di gereja oleh para petugas pelayan liturgi, sedangkan jemaat bisa mengikuti dengan internet di rumah masing-masing. Ibadah online diterapkan mengikuti anjuran pemerintah dengan tujuan untuk meminimalisir kerumuman orang sehingga penyebaran wabah virus corona bisa lebih dikendalikan.

Musik gereja sebagai bagian untuk menunjang atau melayani liturgi senantiasa diperlukan keberadaannya dalam ibadah, begitu juga dalam ibadah yang menggunakan model online. Penggunaan musik dalam liturgi secara online perlu dikelola atau ditata dengan baik, tentunya dengan berbagai penyesuaian yang baru sebagai kebiasaan baru untuk menunjang keberhasilan ibadah tersebut.

Berdasarkan data di lapangan, ternyata ibadah online membawa dampak permasalahan dalam penerapannya, baik bagi sumber daya pelayan liturgi, sarana dan prasarana, musik vokal, musik iringan, jemaat, dan liturgi. Di bawah ini akan diuraikan dan dijelaskan dampak-dampak dan permasalahan yang timbul pada pelaksanaan ibadah online, yaitu:

\section{Sarana dan Prasarana}

Ibadah online membawa dampak perubahan pada sarana dan prasarana yang digunakan dalam ibadah. Sarana jaringan internet menjadi sarana utama masih kurang stabil dan belum merata di semua wilayah. Jaringan internet yang kurang stabil akan mempengaruhi kualitas penyiaran ibadah online dari gereja dan daya tangkap ibadah online bagi jemaat. Suara dan video yang ditampilkan akan terganggu, baik itu terputus atau kurang jelas.

Sarana yang lain yang penting dan yang sebelumnya belum ada dalam ibadah normal adalah peralatan tambahan yang harus ada untuk bisa mengakses internet dan menyiarkannya secara online. Peralatan tambahan tersebut yang digunakan menunjang kualitas audio dan video dalam ibadah online tersebut di antaranya adalah: komputer atau laptop, kamera atau hand phone, microphone, lampu pencahayaan, mixer audio online, software audio dan video online, sound card, dll. Peralatan tersebut di atas selain ada juga perlu memperhatikan pemilihan peralatan yang mempunyai kualitas baik sehingga suara yang dihasilnya menjadi lebih jernih dan videonya menjadi lebih tajam 
gambarnya. Kamera yang digunakan lebih baik bisa lebih dari satu agar sudut pandang di tampilkan tidak terbatas pada satu titik saja.

Semua peralatan tersebut terkadang walaupun sudah dipersiapkan dengan baik, tetapi namanya alat juga terbatas dan terkadang ada gangguan tehnis yang tidak terduga dan bahkan kerusakan alat yang dihadapi sehingga ibadah online juga terhambat, misalnya tidak bisa mulai dengan tepat waktu. Peralatan penunjang ibadah online yang sebagian besar adalah peralatan elektrik tentunya sangat bergantung pada aliran listrik yang tersedia, tetapi kenyataan di lapangan terkadang ini juga tidak bisa dipastikan karena PLN terkadang juga melakukan pemadaman. Aliran listrik yang berhenti tiba-tiba dan apalagi pada saat ibadah online berlangsung tentunya akan menjadikan ibadah online juga terhenti beberapa saat sambil dipersiapkan beralih menggunakan pasokan listrik dari mesin generator.

\section{Musik Vokal}

Musik nyanyian atau vokal dalam ibadah merupakan bagian penting yang mendukung unsur dalam liturgi, dengan nyanyian ini jemaat bisa mengekspresikan wujud iman mereka kepada untuk memuji Tuhan, mengagungkan, bersyukur, doa kepada Tuhan, dan bersaksi kepada saudara seiman. Nyanyian yang paling besar porsinya dalam liturgi adalah nyanyian jemaat, sedangkan nyanyian persembahan adalah nyayian yang diberikan jemaat secara perorangan, vokal group, dan bahkan paduan suara.

Persiapan yang dilakukan oleh petugas pemandu lagu atau pemimpin pujian dalam ibadah online dilaksanakan dengan terbatas, waktu yang digunakan untuk latihan persiapan digereja hanya dibatasi sekali saja untuk latihan bersama pemain musik, dan bahkan terkadang tanpa latihan dengan pertemuan langsung tetapi dengan latihan secara virtual dirumah masing-masing. Model latihan secara virtual ini sedikit banyak juga mempengaruhi keseriusan dan hasil dari latihan musik tersebut, dikarenakan komunikasi pertemuan tidak langsung yang terbatas, juga keseriusan latihan secara mandiri mengakibatkan pemandu lagu atau pemimpin pujian kurang termotivasi dan terkontrol dengan baik. Dengan terbatasnya waktu untuk latihan dan bahkan tidak bisa bertemu latihan secara langsung ini maka berakibat pada penguasaan lagu-lagu oleh pemanadu lagu atau pemimpin punjian menjadi kurang maksimal.

Petugas pemandu lagu atau pemimpin nyanyian jemaat dalam ibadah online dikurangi dari ibadah normal sebelumnya, petugasnya dalam ibadah online hanya mengunakan satu orang yang bertugas dan tidak menggunakan singer atau penyanyi pendamping, sedangkan dalam ibadah normal berjumlah 3 orang atau lebih. Jumlah petugas dibatasi tentunya untuk menjaga kerumunan orang dan jarak antar petugas agar lebih bisa diatur sesuai protokol kesehatan. Berkurangnya jumah pemandu lagu atau pemimpin pujian ini berakibat kurang maksimalnya kekuatan peranan dan fungsi mereka dalam memperkuat dan mendukung nyanyian jemaat pada ibadah online.

Nyanyian pujian dalam ibadah online juga dilaksanakan dengan lebih terbatas, jumlah lagu vokal mengalami perubahan dan berkurang hinga setengah dari ibadah biasanya karena menyesuaikan ketentuan dan anjuran protokol kesehatan dari 
pemerintah. Perubahan tersebut adalah jumlah nyanyian yang digunakan dalam ibadah online menggunakan 3 lagu sedangkan dalam ibadah normal biasanya menggunakan sampai 6 atau 7 lagu.

Selain jumlah lagu vokal berkurang, perubahan yang lain adalah pemilihan dari judul lagu yang kurang bervariatif, artinya lagu yang dipilih adalah lagu yang dianggap umum dan dikuasai oleh jemaat. Variasi lagu vokal kurang mengalami perkembangan atau bertambahnya variasi lagu yang dinyanyikan karena dipilih berdasarkan yang mudah untuk dinyanyikan oleh jemaat dan peranan pemandu lagu atau pemimpin pujian juga kurang maksimal dalam ibadah online.

Keluarga yang tidak bisa mengikuti ibadah online karena keterbatasan alat maka mereka akan mengadakan ibadah secara mandiri dirumah dengan selebaran panduan ibadah yang sudah diedarkan dari gereja tiap minggunya. Pemilihan lagu berdasarkan yang umum dan mudah dinyanyikan dikarena tidak ada pemandu lagu yang biasanya mengajarkan dan memandu lagu untuk jemaat beribadah dirumah. Pemandu lagu dilakukan oleh jemaat secara mandiri dirumah masing-masing tanpa kemampuan secara khusus karena yang penting keluarga bisa memuji Tuhan lewat nyanyian mereka di rumah masing-masing. Lagu yang tidak dikuasai oleh jemaat dalam ibadah mandiri di rumah akan mereka ganti dengan lagu yang bisa mereka nyanyikan atau bahkan mereka lewati dan langsung membaca dan belajar renungan kotbahnya saja. Motivasi jemaat dalam membawakan nyanyian vokal mengalami penurunan karena tidak dalam kebersamaan persekutuan jemaat yang kuat dan meriah di dalam gedung gereja.

Persembahan nyanyian pujian dari jemaat hampir juga tidak bisa dilakukan lagi mengingat serba terbatasnya liturgi dalam ibadah online. Latihan-latihan paduan suara juga praktis banyak terhenti karena memang terbatasnya kesempatan latihan dan juga terbatasnya atau bahkan tidak ada ruang yang diberikan untuk persembahan pujian dalam ibadah. Paduan suara jarang dilakukan dan kalaupun ada dilaksanakan dalam bentuk virtual, itupun dilakukan oleh gereja-gereja besar dengan sarana dan sumber daya manusia yang cukup.

\section{Musik Iringan}

Musik iringan atau musik instrument berperanan penting dalam liturgi, secara umum digunakan untuk mengiringi nyanyian vokal dalam ibadah agar musik vokal bisa dinyanyikan dengan lebih baik dan semarak. Musik pengiring membantu jemaat untuk bisa bernyanyi dengan lebih seragam, penggunaan nada dasar yang tepat dan tempo yang teratur. Persiapan yang dilakukan oleh pemain musik iringan dalam ibadah juga terkendala seperti juga pada petugas pemandu lagu atau pemimpin pujian dalam ibadah online. Waktu yang digunakan untuk latihan persiapan digereja hanya dibatasi sekali saja dan bahkan terkadang tanpa latihan atau latihan dilakukan secara virtual dirumah masing-masing.

Ibadah online membuat sedikit banyak ikut berpengaruh dalam liturgi menjadi terbatas, begitu juga musik iringan terkena dampaknya dan mengalami perbedaan dari ibadah normal sebelumnya. Pengurangan jumlah alat musik pengiring dilaksanakan 
dalam ibadah online karena pemain musiknya juga dikurangi mematuhi protokol kesehatan. Ibadah normal sebelumnya bisa menggunakan beberapa alat musik atau full band, sedangkan dalam ibadah online hanya memakai satu alat musik pengiring inti saja, yaitu menggunakan musik instrumen keyboard. Berkurangnya alat musik yang digunakan ini tentu berpengaruh juga pada keharmonisan, kemeriahan dan kemegahan musik dalam ibadah. Kualitas musikalitas satu alat instrument tentu tidak bisa maksimal dibanding dengan beberapa alat instrumen yang berpadu indah dalam simponi musik, baik itu terbatasnya variasi bunyi melodi, akor ritme atau ekspresi bermusik.

Suasana dalam ibadah online yang berbeda dengan ibadah normal juga mempengaruhi pemain musik pengiring, mereka biasa bermain dihadapan jemaat tetapi harus dirubah dengan berhadapan di depan kamera. Suasana kesakralan dan keagungan ibadah menjadi berkurang karena suasana ibadah online menjadi bertambah dengan peralatan audio dan video online dan hampir mirip dengan suasana di studio atau ruang rekaman.

\section{Jemaat}

Jemaat menjadi subyek penting dalam ibadah, jemaat menjadi kelompok terbesar yang juga disebut umat yang merupakan fokus tolak ukur keberhasilah dari para petugas pelayanan liturgi atau ibadah. Tujuan dari sasaran dari para petugas pelayanan liturgi sebenarnya adalah melayani dan menghantar jemaat agar bisa beribadah dengan lebih baik, lebih bisa menghayati dan merayakan perjumpaan dengan Tuhan Allah dalam ibadah. Begitu juga dengan ibadah online di GKE Jemaat Kalawa sebenarnya disusun dengan berusaha untuk tetap dapat melayani jemaat agar bisa tetap terus beribadah kepada Tuhan sambil menyesuaikan dengan protokol kesehatan yang sudah ditetapkan pemerintah. Perbedaan yang berdampak terhadap jemaat terkait dengan ibadah online dengan ibadah biasa adalah tempat ibadah jemaat. Jemaat yang biasanya menggunakan gedung gereja sebagai tempat bersekutu dan berkumpul untuk beribadah kepada Tuhan menjadi berubah menggunakan tempat di rumah masing-masing.

Suasana ibadah yang biasa dilakukan di gereja dan berubah menjadi di rumah ini tentu sangat berpengaruh bagi jemaat. Kekhusukan dan keseriusan bisa lebih berkurang jika dilakukan di rumah, apalagi tanpa ada tamu dari luar yang menyertai anggota keluarga, sehingga terkadang ibadah di rumah dilakukan jemaat terkesan dengan apa adanya. Kurangnya keseriusan jemaat ini bisa dilihat dari persiapan berpakaian dilakukan tidak seperti ibadah di gereja, terkadang hanya menggunakan pakaian seharihari yang tidak rapi dan kurang sopan. Jemaat juga terkadang tidak mengikuti ibadah dengan tepat waktu, mereka terkesan santai dan akhirnya terlambat dalam beribadah. Posisi tubuh dalam beribadah juga kadang dilakukan dengan santai, bisa sambil tidur, ataupun sambil melakukan kegiatan lain, misalnya: makan, minum, melipat pakaian, ataupun mengerjakan pekerjaan rumah yang lain.

Selain sikap tubuh dan cara berpakaian jemaat dalam ibadah online yang kurang serius, juga terkadang dijumpai respon penjiwaan dan ekspresi mereka ketika beribadah kurang maksimal. Hal ini bisa terjadi karena suasana dan tata ruang rumah kurang 
mendukung dan tidak bisa menggantikan dengan suasana dan tata ruang ibadah di gereja, totalitas respon jemaat akan berkurang ketika yang dilihat adalah layar hand phone, laptop, ataupun televisi yang terbatas. Orang yang sudah lanjut usia yang mempunyai masalah penglihatan dan pendengaran tentunya juga akan lebih terdampak dengan media yang digunakan dalam ibadah online, belum lagi jika dalam keluarga tidak ada anggota yang tidak memiliki, atau tidak mampu menguasai dan menggunaan media ibadah online tersebut maka tidak akan dipakai media tersebut dalam ibadah.

Sarana peralatan ibadah yang dimiliki jemaat untuk ibadah online dirumah tidak bisa disamakan dan selengkap dengan sarana ibadah di gereja. Tidak semua jemaat memiliki internet, dan tidak semua jemaat juga memiliki hand phone atau media online lainnya, sehingga tidak jarang dijumpai ada jemaat yang tidak bisa mengikuti ibadah secara online. Semangat dan motivasi jemaat dalam beribadah online juga berkurang dikarenakan biasanya setiap hari Minggu mereka mendapatkan suasana yang baru, pergi keluar dari rumah, berjumpa dengan banyak jemaat dan bisa saling berinteraksi di gereja, tetapi hal itu harus berubah dan diganti dengan cukup kegiatan ibadah di rumah sendiri dan bertemu bersama anggota keluarga yang sudah rutin dijumpai dalam hidup seharihari.

\section{Liturgi}

Liturgi dalam ibadah online di GKE Jemaat Kalawa dilakukan dengan lebih disederhanakan dari liturgi normal sebelumnya, baik durasi waktu, petugas liturgi, maupun unsur-unsur liturgi di dalamnya. Durasi waktu yang digunakan dalam ibadah online menjadi paling lama 1 jam, sedangkan pada ibadah normal bisa sampai 2 jam. Begitupun dampak kepada petugas yang melayani saat ibadah online hanya menggunakan empat sampai enam orang saja, berbeda dari sebelumnya yaitu sepuluh sampai lima belas orang petugas, dimulai dari pendeta, penatua diakon, penerima tamu, pengedar kantong persembahan, song leader, pemusik, multimedia dan soundman. Unsur-unsur liturgi menggunakan unsur utama dan yang memungkinkan digunakan dalam ibadah online, misalnya persebahan pujian dan persembahan uang ditiadakan. Nyanyian jemaat dalam ibadah online disederhanakan dan dipotong menjadi 3 lagu, sedangkan sebelumnya dalam ibadah normal menggunakan 6-7 lagu.

Pelaksanaan ibadah hanya dilaksanakan dan difokuskan pada ibadah hari Minggu, sedangkan ibadah kategorial dan rumah tangga ditiadakan. Model dan variaso liturgi yang digunakan dalam ibadah online terbatas untuk dikembangkan, berbeda dengan ibadah normal biasanya bisa menggunakan variasi ibadah yang lebih beragam, misalnya: ibadah kreatif, ibadah etnik, dan lain-lain.

Para pelayan litugi juga harus menyesuaikan ruang gerak dengan pengaturan dalam ibadah online yang lebih terbatas dari pada ibadah normal biasanya, ruang gerak para pelayan terbatas pada bidang tangkapan kamera saja, sedangkan dalam ibadah normal ruang gerak lebih luas sesuai dengan pandangan jemaat yang hadir di dalam gedung gereja. Terkadang bisa dijumpai ada juga petugas yang belum terbiasa dengan tangkapan kamera sehingga terkesan canggung dan pandangan mereka terkadang tidak 
bisa fokus ke kamera, Suasana dalam proses pelaksanan liturgi ibadah online di dalam gedung gereja yang dilakukan di depan kamera dan tidak bersama secara langsung di hadapan persekutuan jemaat, terkadang itu dirasakan berpengaruh pada totalitas keseriusan para petugas pelayan liturgi. Suasana para pelayan liturgi di depan jemaat secara langsung bisa dirasakan adalah suasana ibadah, sedangkan suasana di depan kamera terkesan seperti sebuah tontotan atau pertunjukkan, hal inilah yang terkadang suasana sakral dan agung dalam ibadah menjadi berkurang.

\section{Dampak Positif Ibadah Online}

Ibadah online juga bisa membawa dampak yang positif yang menjadi kekuatan dalam penerapannya. Di bawah ini juga akan diuraikan dan dijelaskan dampak-dampak positif yang menjadi kekuatan pada pelaksanaan ibadah online di GKE Jemaat Kalawa. Dampak positif tersebut ialah sebagai berikut:

\section{Sumber Daya Pelayan Liturgi}

Konsep ibadah online bisa dilakukan atau diikuti dari mana saja menjadi salah satu kelebihan bagi sumber daya petugas pelayan liturgi, mereka bisa mempersiapkan dan melakukannya dari rumah masing-masing sehingga lebih praktik karena tidak harus pergi ke gereja. Pengkotbah dan petugas lain bisa juga membuat live streaming dari rumah asal peralatan online telah tersedia, hal ini bisa menjadikan kinerja para pelayan liturgi menjadi lebih efektif dan efisien.

\section{Sarana dan Prasarana}

Persiapan sarana dan prasarana yang perlu dipersiapkan di dalam gedung gereja ada yang menjadi berkurang sehingga bisa memudahkan pekerjaan dan mempersingkat waktu persiapannya. Misalnya; pengaturan tempat duduk tidak sebanyak ibadah normal, persiapan ruang lingkup yang digunakan menjadi lebih kecil karena hanya menggunakan ruang panggung altar di depan dan bukan semua bagian gedung digunakan. Kelebihan yang lain yang dirasakan dalam ibadah online adalah makna gereja yang dibatasi sebagai gedung menjadi bergerser ke makna gereja yang lebih luas, artinya dirumah masingmasing jemaat bisa menjadi gereja bagi anggotanya untuk beribadah bersama dan ketergantungan bahwa beribadah harus di gedung gereja dengan segala sarananya menjadi berkurang.

\section{Musik}

Pemilihan lagu dalam ibadah online menggunakan lagu yang lebih umum atau terbiasa dinyanyikan jemaat sehingga jemaat bisa lebih mudah untuk menyanyikannya. Selain memudahkan jemaat dalam menyanyikan nyanyian, hal ini juga lebih memudahkan pemandu lagu dan pemain musik dalam melaksanakan tugasnya karena tingkat kesulitan lagu menjadi berkurang. 


\section{Jemaat}

Jemaat dalam melakukan ibadah online cukup dirumah masing-masing sehingga lebih mudah dalam mempersiapkannya, karena jemaat tidak perlu terburu buru, lebih hemat biaya, waktu dan juga tenaga. Ibadah online dilakukan dirumah sehingga jemaat dalam proses mengikuti ibadah juga tidak terlalu kaku bahkan terkesan santai karena dirumah sendiri beserta keluarga tanpa ada tamu yang terlibat. Ibadah yang dilakukan dirumah juga membuat jemaat lebih mandiri dalam beribadah, semua keluarga bisa berperan dan terlibat dalam pelayanan ibadah, dan persekutuan hubungan anggota keluarga menjadi lebih kuat. Keuntungan yang lain dapat dirasakan oleh jemaat adalah bagi jemaat yang sudah lanjut, lemah tubuh atau sakit, karena mereka tidak perlu pergi datang ke gereja tetapi cukup dirumah bisa beribadah.

\section{Liturgi}

Ibadah online disusun dengan liturgi yang disederhanakan sehinga lebih singkat dan padat, ibadah juga tidak terkesan lama dan bertele-tele, misalnya tidak ada pengulangan lagu yang dinyanyikan dengan berlebihan. Model liturgi online juga dibuat berbabis jaringan internet sehingga bisa diakses dengan lebih luas dari mana saja tanpa terbatas jarak, oleh siapa saja dan kapan saja.

\section{Penatalayanan Musik Gereja Musik Gereja Dalam Ibadah Online}

Penatalayanan ibadah pada masa pandemi berpengaruh juga pada bentuk dan unsur dalam penyusunan liturgi yang digunakan yaitu dengan munculnya bentuk litugi atau ibadah online. Liturgi dalam ibadah online mengalamai perubahan dari liturgi biasanya karena menyesuikan dengan kondisi atau situasi pada masa pandemi. Perubahan liturgi ini sesuai juga dengan pemahaman gerakan gereja reformasi, seperti yang tertuang dalam istilah "ecclesia reformata, semper reformanda" yang yaitu gereja reformasi selalu bereformasi, atau dapat dipahami pula sebagai "liturgia reformata semper reformanda", yaitu bahwa liturgi akan terus bereformasi atau diperbaharui, tidak ada liturgi yang mutlak, ideal atau mapan, sehingga liturgi akan terus dinamis mengikuti perkembangan zaman dan konteks yang ada (Rahman, 2012).

Covid-19 membawa dampak yang sangat besar pada agama Kristen dalam tata cara beribadah. Dalam hal ini, ibadah yang sebelumnya dilakukan secara tatap muka di gereja, kehadiran Covid-19 dan sesuai aturan pemerintah ibadah di lakukan di rumah secara virtual dalam ibadah online di rumah. Perubahan model ibadah yang dirasakan di masa pandemi covid-19 adalah yang sebelumnya dilakukan di gedung gereja beralih ke ibadah rumah. Ibadah pada dasarnya merupakan perjumpaan manusia dengan Allah dan persekutuan melalui umatNya di mana Yesus Kristus sangat menggetarkan hati dan mampu mengubahkan kehidupan orang percaya kepada Tuhan serta menyelamatkan dari maut yang akan membinasakan kehidupan orang percaya seperti Covid-19 (Widjaja, 2021).

Ibadah yang dilakukan di rumah atau gereja rumah bukan merupakan suatu hal yang baru sebab dalam Alkitab sudah dijelaskan mengenai ibadah rumah. Ibadah dalam 
Alkitab dikenal dengan istilah komunal (berjemaah) dan personal. Ibadah secara komunal yakni kebaktian di Gereja dan kebaktian rumah tangga. Dalam hal ini, ibadah komunal sudah ada sejak zaman Abram yang mana ibadah dilakukan hanya dalam lingkup keluarga atau suku. Abram misalnya beberapa kali mendirikan mezbah dalam perjalanannya bersama keluarga ketika merespon panggilan Allah Yahweh untuk menuju tanah yang akan dituntunNya. Abram, bapa Leluhur dicatat dalam Kej.12:8 di sebelah timur Betel; lalu 13:18 di Mamre mendirikan kemah untuk ibadah keluarga dan orang-orang yang bersama dengannya (Rubyantara, 2020).

Rustiyati dalam buku Kemandirian Gereja DGI, menjelaskan bahwa Penatalayanan menjadi tugas yang diberikan Allah kepada manusia untuk mengelola secara bertanggung jawab segala sumber daya yang dimilikinya (DGI, 1985). GKE Jemaat Kalawa melaksanakan penatalayanan dengan berusaha untuk mengelola dan bertanggung jawab atas semua sumber daya yang ada dan yang Tuhan sudah karuniakan di dalam kehidupan bergereja. Sumber daya para petugas liturgi diatur sedemikian rupa agar terus bisa melayani jemaat mesikipun dalam bentuk ibadah online. Setiap petugas diberikan tugas pelayanan sesuai dengan bidangnya masing-masing dan diatur serta ditetapkan dalam jadwal petugas pelayanan liturgi. Gereja juga berusaha untuk mengelola, menyediakan dan memperlengkapi sarana dan prasara untuk bisa digunakan melayani jemaat dengan lebih baik dalam ibadah online.

Penatalayanan melibatkan seluruh umat, karena bukan hanya pendeta atau majelis gereja yang tugasnya memastikan bahwa karunia Allah telah digunakan untuk mendukung misi Kristus, melainkan seluruh umat (Coster, 2011). GKE Jemaat Kalawa dalam melakukan penatalayanan berusaha untuk melibatkan peran jemaat dalam ibadah online. Gereja berusaha agar semua jemaat dapat terlibat dan mengikuti ibadah online sehingga gereja menyusun liturgi yang lebih sederhana dan meminimalisir serta memberikan solusi untuk setiap kendala bagi jemat dalam mengikuti ibadah online.

Menurut Cooper White, penatalayanan tidak semata-mata terkait atau terutama dengan uang maupun barang. Pelaksanaan penatalayanan diikuti oleh spiritualitas, dalam artian bahwa pelaksanaan penatalayanan disertai dengan memikul salib Tuhan (Cooper, 2009). GKE Jemaat Kalawa tidak hanya sebatas mengelola sumber daya dan sarana prasarana semata, tetapi yang lebih penting juga memperhatikan dan meningkatkan bidang spiritualitas jemaat, khususnya dalam ibadah online. Ibadah online disusun dengan tujuan untuk melayani jemaat agar tetap bisa beribadah dan kehidupan spiritualitasnya bisa terus terjaga dan ditingkatkan.

Rikchard B. Cunningham berpendapat bahwa seluruh penatalayanan dalam gereja mengenai sumber dayanya harus berkontribusi pada peneguhan dan menyatukan gereja, sebagai persiapan bagi pelayanan dan misi di dunia (Cunningham, 1989). Penatalayanan GKE Jemaat Kalawa juga diarahkan untuk dapat menjaga kesatuan jemaat agar terus terjalin meskipun pada masa pandemi Covid-19 dan dengan beribadah secara online. Jemaat bisa saling menopang dalam melaksanakan ibadah online, misalnya jika ada jemaat yang terbatas sarana dirumanya sehingga tidak bisa mengikuti ibadah online 
maka bisa bergabung ikut dengan jemaat terdekat atau keluarganya agar tetap bisa mengikuti ibadah online dirumah mereka.

Semenjak diberlakukannya tanggap darurat covid-19, gereja melaksanakan penatalayanan menyesuaikan dengan arahan dari pemerintah dengan melakukan protokol kesehatan, menghindari kerumunan, dan mematuhi program 3M, yakni dengan memakai masker, menjaga jarak dan rajin mencuci tangan. Penatalayan gereja mengambil keputusan untuk semua kegiatan yang bersifat tatap muka ditiadakan untuk mencegah penularan wabah. Maka dari itu, gereja mengganti kegiatan ibadah secara online yang dapat diakses langsung dari rumah masing-masing dengan mengakses media sosial milik gereja. Dampak covid-19 membawa banyak perubahan dalam pelayanan musik gereja selama pandemi, gereja melakukan ibadah online dengan segala keterbatasannya karena mematuhi protokol kesehatan, tetapi gereja juga terus berusaha untuk melayani jemaat dengan tetap melayani jemaat untuk tetap dapat beribadah dengan baik walaupun dengan bentuk ibadah online.

\section{Sumber Daya Pelayan Litrugi}

GKE Jemaat Kalawa dalam masa tanggap darurat Covid-19 tetap terus berusaha melayani jemaat agar tetap dapat beribadah sehingga gereja melaksanakan ibadah dalam bentuk online dengan segala keterbatasannya. Ibadah online dilaksanakan dengan membatasi jumlah petugas pelayanan yang terlibat, hal ini merupakan cara membatasi tingkat kerumuman orang di dalam gedung gereja. Gereja melakukan penatalayanan ibadah dengan membuat dan menyusun jadwal para petugas yang bertugas di ibadah tiap minggu dalam ibadah online agar bisa berjalan dengan lancar. Para petugas yang dilibatkan dalam ibadah online hanya menggunakan empat sampai enam orang saja, berbeda dari sebelumnya yaitu sepuluh sampai lima belas orang petugas, dimulai dari pendeta, penatua diakon, penerima tamu, pengedar kantong persembahan, song leader, pemusik, multimedia dan soundman.

Para petugas pelayan liturgi yang sudah ditetapkan oleh gereja walaupun berkurang hampir separo dari ibadah biasanya tetap dengan dasar pemilihan bahwa mereka dipandang mampu untuk melayani dengan baik dan bertanggung jawab dalam tugasnya sehingga ibadah online tetap bisa berlangsung dengan lancar. Gereja juga berusaha memberikan kesempatan dan waktu latihan bagi para petugas pelayan liturgi yang ada, meskipun hanya satu kali latihan di gedung gereja dan selebihnya bisa latihan secara mandiri atau virtual dirumah masing-masing. Seiring perkembangan wabah corana dan aturan pemerintah tentang ibadah di gereja, gereja juga akan terus menyesuaikan dalam penatalanan kepada jemaat, gereja terus mencari dan memperlengkapi kekurangan sumber daya pelayanan liturgi, khususnya yang terkait dengan petugas yang menangani IT (informasi dan tehnologi) sehingga ibadah online bisa dilaksanakan dengan lebih baik. 


\section{Sarana dan Prasarana}

GKE Jemaat Kalawa terus berusaha memperlengkapi dan menyesuaikan penatalayanan dalam bidang sarang dan prasarana yang menunjang dan mendukung kelancaran ibadah online, misalnya gereja menyediakan dan memilih jaringan internet yang dirasa kuat dan mampu dalam mendukung ibadah online. Gereja juga memperlengkapi peralatan audio ataupun video yang sesuai dan mendukung dengan jaringan internet sehingga ibadah online bisa dilaksanakan dengan lebih baik. Gereja juga membuat dan membangun aplikasi jaringan media online yang dirasa lebih umum dan lebih mudah digunakan oleh jemaat dalam mengakses ibadah online, misalnya Facebook, Instragram, group WhatsApp dan ataupun Youtube.

Penatalayanan yang dilakukan oleh gereja juga terkait dengan pasokan aliran litrik sebagai sarana yang vital bagi kelangsungan ibadah online sehingga gereja juga melengkapi dengan peralatan mesin generator listrik untuk mengantisipasi jika listrik PLN tiba-tiba mati. Sebagai sarana wajib sesuai protokol kesehatan juga disediakan gereja, yaitu tempat mencuci tangan dengan sabun, larutan hand sanitizer, anjuran wajib bermasker, mengatur tempat agar ada jarak yang aman antar petugas, dan membatasi jumlah petugas yang masuk dalam gereja menjadi hal yang dilaksanakan dalam melaksanakan ibadah online.

\section{Musik Vokal}

Musik vokal merupakan bagian yang penting dalam ibadah sehingga GKE Jemaat Kalawa berusaha melakukan penatalayan dalam bidang ini, yaitu: Gereja tidak menghilangkan peran petugas pemandu lagu, tetapi gereja menyediakan satu petugas pemandu lagu dan mengaturnya dengan menyusun jadwal petugas pemandu lagu di tiap minggu dalam ibadah online. Gereja juga berusaha menyusun dan memilih lagu yang dinyanyikan dalam ibadah online tiap minggu dengan jumlah yang lebih terbatas. Pemilihan lagu juga didasari pada lagu-lagu yang dianggap mudah dan biasa untuk dinyanyikan jemaat karena keterbatasan sarana mereka dalam ibadah online. Meskipun lagu yang dinyanyikan lebih sedikit dan sederhana dalam ibadah online, gereja tetap berusaha agar lagu-lagu tersebut bisa dinyanyikan dengan lebih baik sehingga gereja menata, mengatur dan menyediakan waktu latihan secara terbatas di gereja sambil ditambahkan latihan masing-masing secara mandiri.

\section{Musik Iringan}

Musik instumen pengiring nyanyian jemaat merupakan bagian yang penting dalam ibadah sehingga GKE Jemaat Kalawa berusaha melakukan penatalayan dalam bidang ini, yaitu: gereja tidak menghilangkan pemain musik, tetapi gereja tetap menyediakan satu petugas pemandu lagu dan mengaturnya dengan menyusun jadwal petugas pemain musik di tiap minggu dalam ibadah online. Meskipun lagu yang dinyanyikan lebih sedikit dan sederhana dalam ibadah online, gereja tetap berusaha agar lagu-lagu tersebut bisa diiringi dengan musik yang lebih baik sehingga gereja menata, mengatur dan 
menyediakan waktu latihan secara terbatas di gereja sambil ditambahkan latihan masingmasing secara mandiri.

\section{Jemaat}

GKE Jemaat Kalawa berusaha agar jemaat dapat terlibat dan mengikuti ibadah online dengan maksimal, sehingga gereja perlu mengetahui permasalahan yang ada di jemaat dalam ibadah online agar bisa melakukan panatalayanan bagi jemaat agar bisa mengikuti ibadah online. Penatalayanan yang dilakukan gereja kepada jemaat dalam usaha pelaksanaan ibadah online adalah: gereja berusaha membuat dan menyusun rangkaian ibadah online dengan lebih sederhana agar bisa diikuti oleh semua jemaat, gereja juga membuat fotocopy edaran liturgi ibadah online dan membagikannya kepada jemaat setiap hari jumat atau sabtu agar jemaat lebih mudah mengikuti ibadah online, gereja juga mengarahkan kepada jemaat yang tidak bisa atau memiliki peralatan ibadah online untuk bergabung ke jemaat terdekat atau keluarganya yang bisa mengadakan ibadah online dirumahnya, gereja berusaha meningkatkan peran pemuda yang memiliki dan menguasai media online dalam memelopori dan mendukung keluarganya mengikuti ibadah online, gereja juga berusaaha terus memantau kabar keadaan jemaat dengan komunikasi tidak langsung atau komunikasi jarak jauh dan meningkatan kegiatan perkunjungan bagi jemaat yang membutuhkan.

\section{Liturgi}

GKE Jemaat Kalawa berusaha menyusun dan menyediakan liturgi bagi jemaat dengan disesuaikan kondisi pandemi Covid-19 dalam bentuk ibadah online. Liturgi tersebut lebih sederhana tetapi tetap berusaha tidak menghilangkan esensi dan makna ibadah bagi jemaat. Liturgi online juga dibuat dan dicopy untuk tiap ibadah minggunya dan dibagikan bagi jemaat dengan maksud agar jemaat tetap bisa beribadah walaupun tidak bisa mengakses ibadah online. Gereja terus berusaha menyesuikan dan mengembangkan ibadahnya sesuai dengan perkembangan persebaran wabah corona yang menerapkan kebiasaan normal baru sehingga mulai juga bisa diterapkan beberapa ibadah secara normal terbatas di gereja ataupun dirumah jemaat, misalnya ibadah pemuda, ibadah rumah tangga, ibadah pernikahan dan juga ibadah kedukaan dengan tetap menjalankan protokol kesehatan dan membatasi pesertanya. Sakaramen perjamuan kudus juga tetap dilaksanakan walaupun secara online dirumah masingmasing, sebelumnya ada petugas yang sudah membagikan roti dan anggur ke masingmasing jemaat. Gereja juga memberikan kesempatan kepada jemaat untuk tetap bisa memberikan persembahan dana dengan cara membagikan amplop ke jemaat dan selanjutnya bisa diserahkan kembali ke gereja.

\section{Implikasi}

Majelis jemaat GKE Kalawa di tengah pandemi virus Covid-19 dengan segala keterbatasan terus berusaha untuk dapat menjalanan tiga tugas panggilannya sebagai gereja (Singgih, 1997:1), yaitu: koinonia (bersekutu), marturia (bersaksi), dan diakonia 
(melayani). Bidang persekutuan adalah hal yang paling terkendala pada pandemi Corona ini karena persekutuan merupakan kegiatan perjumpaan jemaat untuk berhimpun bersama dalam ibadah. Meskipun demikian GKE Jemaat Kalawa berusaha tetap membangun persekutuan jemaat sebagai tubuh Kristus dengan menyediakan atau mengadakan ibadah yang tidak bertemu secara langsung yaitu dalam bentuk ibadah online. Ibadah online diterapkan mengikuti anjuran pemerintah dengan tujuan untuk meminimalisir kerumuman orang sehingga penyebaran wabah virus corona bisa lebih dikendalikan. Ibadah online di GKE Jemaat Kalawa dibuat dengan lebih sederhana dari liturgi normal sebelumnya, baik durasi waktu, petugas liturgi, maupun unsur-unsur liturgi di dalamnya. Meskipun liturgi online lebih sederhana tetapi tetap berusaha tidak menghilangkan esensi dan makna ibadah bagi jemaat.

\section{Rekomendasi untuk Penelitian Lanjutan}

Penelitian ini hanya mencakup GKE Jemaat Kalawa. Peneliti memberikan rekomendasi agar peneliti lainnya dalam melakukan kajian lebih luas, bukan hanya GKE Jemaat Kalawa. Metode penelitian juga bisa menggunakan metode kuantitatif agar dapat memperkaya kajian dan topik serupa dengan penelitian ini.

\section{Kesimpulan}

Ibadah online diterapkan mengikuti anjuran pemerintah dengan tujuan untuk meminimalisir kerumuman orang sehingga penyebaran wabah virus corona bisa lebih dikendalikan. Ibadah online di GKE Jemaat Kalawa dibuat dengan lebih sederhana dari liturgi normal sebelumnya, baik durasi waktu, petugas liturgi, maupun unsur-unsur liturgi di dalamnya. Dampak hambatan yang dijumpai dalam melaksanakan ibadah online adalah jaringan internet yang belum merata, peralatan media online yang tidak dimiliki semua jemaat; petugas pemusik gereja lebih terbatas; penggunakan lagu dikurangi; aspek musikalitas musik iringan kurang maksimal, persekutan sosial dalam jemaat menjadi berkurang; liturgi yang disederhanakan sehingga kurang meriah, ibadah di rumah dilakukan jemaat terkesan dengan apa adanya dan kurang serius; suasana kesakralan dan hikmat dalam ibadah menjadi berkurang, dan lain-lain. Dampak positif yang menjadi kelebihan ibadah online di antaranya adalah ibadah online dibuat dengan lebih singkat dan padat sehingga lebih efektif dan efisien; pemilihan lagu menggunakan lagu yang lebih umum atau terbiasa dinyanyikan jemaat; cukup beribadah dirumah masing-masing sehingga jemaat lebih mudah dalam mempersiapkannya, tidak perlu terburu buru, lebih hemat biaya, waktu dan juga tenaga; liturgi online dibuat berbabis jaringan internet sehingga bisa diakses dengan lebih luas dari mana saja tanpa terbatas jarak, oleh siapa saja dan kapan saja.

Bentuk-bentuk usaha penalatalayanan ibadah online adalah ibadah online dilaksanakan dengan membatasi jumlah petugas pelayanan yang terlibat sesuai jadwal yang sudah ditetapkan; gereja menyediakan satu pemandu lagu dan satu pemain musik yang bertugas; gereja memberikan kesempatan waktu latihan bagi pemusik gereja satu kali latihan di gedung gereja dan selebihnya bisa latihan secara mandiri atau virtual 
dirumah masing-masing; menggunakan lagu yang dianggap mudah dan biasa untuk dinyanyikan jemaat; gereja juga membuat fotocopy edaran liturgi ibadah online dan membagikannya kepada jemaat setiap hari jumat atau sabtu agar jemaat lebih mudah mengikuti ibadah online pada hari Minggu; gereja juga terus berusaha menyesuikan dan mengembangkan ibadahnya sesuai dengan perkembangan persebaran wabah corona yang menerapkan kebiasaan normal baru sehingga mulai juga bisa diterapkan beberapa ibadah secara normal terbatas di gereja ataupun dirumah jemaat, misalnya ibadah pemuda, ibadah rumah tangga, ibadah pernikahan dan juga ibadah kedukaan dengan tetap menjalankan protokol kesehatan

\section{Rujukan}

Coster, Pam. (2011). Stewardship: Invation, Investmen, Inspiration", Liturgy 26.

Cunnigham, Rikchard B. (1989). Creative Stewardship. Nashville: Abingdon press.

DGI. (1985). Penatalayan Dana Gereja dalam DGI. Jakarta: DGI.

Dirjen Kesehatan. (2020). Panduan Pencegahan Penularan Covid-19 di Tempat dan Fasilitas Umum. Jakarta: Kemenkes RI.

Dirjen P2P. (2020). Pedoman Kesiapsiagaan Menghadapi Coronavirus Disesase (COVID19). Jakarta: Kemenkes RI.

F.I. Widjaja, F.M. Boiliu, D.S.B. Prasetya, dkk. (2021). "Menuju Evolusi Ibadah Kristen di Masa Pandemi Covid-19". Jurnal Teologi Berita Hidup. Vol 3, No 2

Rahman, Rasid. (2012). Pembimbing ke dalam Sejarah Liturgi, Jakarta: BPK Gunung Mulia. Rubyantara Jalu Permana dan Sonny Eli Zaluchu. (2020). "Penulis Loh Batu Kedua Sepuluh Perintah Allah: Analisis terhadap Keluaran 34:1,28," PASCA: Jurnal Teologi dan Pendidikan Agama Kristen, Vol 16, No 1

Singgih, E. G. (1997). Reformasi dan transformasi Pelayanan Gereja Menyongsong Abad ke-21, Jogjakarta: Kanisius.

White, Michael L. Cooper. (2009). Christian Stewardship In The Light Of A Theology of The Cross. Dialog: Journal of Theology 48. 